\title{
Improving Environmental Permitting Systems: Integrated Permits in the Netherlands
}

\author{
Hanna Dürtge Tolsma \\ Department of Administrative Law and Public Administration \\ University of Groningen, Netherlands \\ h.d.tolsma@rug.nl
}

\section{ABSTRACT}

Environmental law originally developed in a fragmented way (sectoral legislation protecting water, soil or air). This fragmented approach towards environmental protection caused problems. Citizens and businesses applying for a permit are confronted with a range of procedures with a variety of different time limits, assessment criteria and legal remedies. Comparative law research shows that the integration of legislation in the field of environmental law is a growing trend. Policymakers feel the necessity to integrate decisionmaking in order to optimise the protection of the environment. The first part of this article contains a brief overview of the concept of an integrated process for the granting of environmental permits. The second part discusses the idea of environmental model 4 permit, which has been put forward in the Netherlands. It is questionable if this specific concept of integrated environmental permitting can be achieved within the constraints of Dutch administrative law.

Key words: environmental permitting, integrated approach, integrated environmental permit, rule of purpose-specific powers

JEL: K23, K41

\section{Introduction}

Integrated environmental permits is a topical issue in many countries such as Germany, Belgium and the Netherlands. In the Netherlands, the General Act on Environmental Permitting introduced in October 2010 radically changed the legal framework of environmental permits. ${ }^{1}$ Until then, environmental permits were split up over a variety of laws and regulations. Citizens and businesses seeking a permit were confronted with a range of procedures entailing a variety of different time limits, assessment criteria and legal remedies. The GAEP is intended to address these problems through the procedural integration of permits. One step further is the idea of a so-called

1 In Dutch: Wet algemene bepalingen omgevingrecht (Wabo), Stb. 2008, 496. 
"model 4" permit system which refers to a single integrated assessment framework. ${ }^{2}$ An advantage of one single integrated assessment framework is that the competent public authority will be able to consider various aspects of the law (such as the environment, nature conservation and spatial planning) in their totality, unimpeded by the constraints of a variety of different assessment frameworks. This would be in line with the "integrated approach" of the Industrial Emissions Directive at EU level.

A number of legal problems have been identified in the literature in relation to this permit model. ${ }^{3}$ In the first place, it is assumed that an integrated framework will have undesirable consequences in terms of judicial review. The integration of various aspects of environmental law in a single assessment framework will probably result in a fairly broad formulation of the aspects (such as "protection of the physical living environment") under which light a permit application will have to be evaluated. Such a vague, general formulation of the public interest to be protected will give rise to considerable constraints for the courts when reviewing decisions on permit applications. Reduced judicial review also entails the risk that the granting of permits will become more arbitrary. Public authorities will acquire more freedom to use their own discretion, and this could make it easier to ignore certain specific aspects that have been integrated in the broad assessment framework. In the third place, integrated permitting might adversely affect legal certainty. If public authorities have more discretion when balancing interests, it becomes more difficult to determine in advance what weight will be given to which interests, and this is undesirable from a legal protection point of view.

These legal problems relate to the Dutch rule of purpose-specific powers (specialiteitsbeginsel), comparable to the German Bestimmtheitsgebot. ${ }^{4}$ This fundamental principle of public law requires that the legislator should formulate precise substantive norms as to content and purpose of administrative authority. The central question is: Can integrated environmental permits (the idea of "model 4") be achieved within the conditions of the Dutch rule of purpose-specific powers? In the first part the discussion on integrated environmental permits in Germany, Belgium and the Netherlands will be presented. This comparative law study will provide knowledge about the extent to which the (proposed) law provides for substantive integrated environmental permits (Section 2). In the second part the permitting model 4 will be evaluated in the light of the Dutch rule of purpose-specific powers (Section 3-4). The article concludes with some final remarks (Section 5).

2 Kamerstukken II, 2004-2005, 29 383, nr. 18. Four models are described in this letter to the Lower House.

3 For example: Schlössels (2006, pp. 153-169).

4 The rule of purpose-specific powers also means that a public authority may only exercise a power in the framework of the legislation on which that power is based. This principle is therefore also comparable with the principle of conferred powers, a general principle of Union Law. 


\section{Concept of Integrated Environmental Permitting}

This section contains a brief overview of (proposed) legislation in the field of integrated environmental permits at the EU level and in Germany, Belgium and the Netherlands. This part of the research will give insight into the concept of integrated environmental permits and, in particular, the "model 4" environmental permit considered in the Netherlands.

\subsection{EU: Industrial Emissions Directive}

An integrated system of prevention and control of pollution was recommended in the early' 90 s because of the recognition that regulation over the release of substances into one environmental medium (e.g. air, land, water) can result in shifting the substance to another medium. The fragmented approach in law and policies towards pollution control (focusing on each medium separately) was considered both ineffective and inefficient. At the EU level, the IPPC Directive (96/61/EC) marks a shift from single-medium to multi-media legislation by implementing an integrated approach towards pollution control. The preamble states in recital 9: "[...] this Directive establishes a general framework for integrated pollution prevention and control; whereas it lays down the measures necessary to implement integrated pollution prevention and control in order to achieve a high level of protection for the environment as a whole; whereas application of the principle of sustainable development will be promoted by an integrated approach to pollution control."

In 2010 the IPPC Directive is rearranged with six other Directives into the Directive on Industrial Emissions (Directive 2010/75/EC). Chapters I, II and VII of the IE Directive correspond to a large extent to the content of the IPPC Directive. On the whole there are no major changes with regard to the integrated approach. The core of the integrated approach is regulated in chapter II of the IE Directive. The IE Directive prescribes an integrated approach to the prevention and control of activities listed in Annex I to the directive (such as energy industries, chemical industry and metal industry). The integrated approach is realised through a permit. Member States must take the necessary measures to ensure that no installation or combustion plant, waste incineration plant or waste co-incineration plant is operated without a permit (Article 4 IE Directive).

Article 14 and 15 of the IE Directive require the application of emission limit values and/or equivalent parameters or technical measures based on BAT (Best Available Techniques) in combination with case-specific considerations which account for the technical characteristics of the installation concerned, its geographical location and the local environmental conditions. These requirements imply a process of weighing and balancing environmental interests in order to achieve an integrated decision (technology based approach). The substantive integration can be achieved through case-specific trade-offs (BAT - requirements against site - specific technical, geographical 
and environmental factors) and generic environmental trade-offs (BAT based emission standards and environmental quality standards) (Bohne \& Dietze, 2004, pp. 200-201). Information on BAT is exchanged between Member States and Industries through BAT reference documents published by the Commission (Article 13). The BAT conclusions in these documents are the reference point for setting the permit conditions (Article 14(3)). ${ }^{5}$ If the BAT conclusions do not cover all potential environmental effects, the competent authority has the task of determining the BAT itself for the specific case on which it bases the permit. Public authorities may deviate from emission levels associated with the best available techniques as laid down in BREF documents (Article 15 (4)). However, the possibility of taking specific circumstances into account is limited. Deviation is only allowed in specific cases, on the basis of an assessment of the environmental and economic costs and benefits taking into account the technical characteristics of the installation concerned, its geographical location and the local environmental conditions.

It is important to note that the IE Directive does not require that Member States combine sectoral environmental laws or integrate sectoral permits in a single environmental permit. In order to guarantee an effective integrated approach Member States shall take the measures necessary to ensure that the conditions of, and the procedures for the granting of the permit are fully coordinated where more than one competent authority or more than one operator are involved or more than one permit is granted (Article 5(2) IE Directive).

\subsection{Germany: Integrierte Vorhabengenehmigung}

In Germany, the idea of creating a comprehensive Environmental Code (Umweltgesetzbuch, UGB) persisted for a long time. ${ }^{6}$ A centerpiece of this Environmental Code would be the integrated project authorisation model (integrierte Vorhabengenehmigung, iVG). After years of preparation (starting in the 1970s) a draft proposal was presented to parliament in 2008. However, the Federal Government was ultimately unable to agree on a common draft (Scheidler, 2009, pp. 173-176). Eventually only a reduced reform of environmental law took place and currently the idea of an Environmental Code is no longer on the political agenda (Müggenborg \& Hentschel, 2010, p. 961). However, for the purpose of this research it is relevant to discuss the proposed integrated project authorisation model.

The intended result of the integrated environmental permit was to end the many differences of permit proceedings. Proceedings are combined, harmonised and simplified. According to the explanatory memorandum the permit proceeding will become more transparent, clear and simple

5 Compared to the IPPC Directive, the IE Directive establishes a stronger legal role for BAT conclusions.

6 See for a description of the development of the UGB for example Knopp (2009, pp. 121-125). 
(Begründung des Entwurfs zu E-UGB-I, p. 22). The integrated project authorisation model is regulated in Chapter 2 of the UGB I. ${ }^{7}$ The integrated project authorisation model contains elements of substantive integration with regard to the immissionrechtliche and wasserrechtliche permit. The integrated project authorisation model provides for procedural integration of permits that have nothing to do with the protection of the environment (such as the building permit). The assessment frameworks for these permits are separated (no single assessment framework). The procedural integration of these permits follows from $\S 59$ Abs. 1. UGB I. § 59 Abs. 1. UGB I: "Die Genehmigung schließt andere das Vorhaben betreffende behördliche Entscheidungen ein, insbesondere öffentlich-rechtliche Genehmigungen, Zulassungen und Verleihungen mit Ausnahme von planerischen Genehmigungen, die in einem Verfahren mit Öffentlichkeitsbeteiligung erteilt werdern, Planfeststellungen, Zulassungen bergrechtlicher Betriebspläne und behördliche Entscheidungen auf Grund atomrechtlicher Vorschriften".

\subsection{Belgium: omgevingsvergunning}

On 19 April and 19 July 2013 the Regional Government of the Flemish Region of Belgium approved a draft Act to introduce an Environmental Permit (omgevingsvergunning). Before this approved draft there had already been proposals to integrate the permit dealing with the operation of activities and installations that can potentially have an impact on the environment and the building permit in one integrated environmental permit. The objective of these proposals was to improve the functioning of the procedural link (koppelingsmechanisme) in practice between these two permits. The former proposals were intended to integrate the assessment of the building permit within the proceedings for an environmental permit. ${ }^{8}$ The result of this integrated proceeding was that there was one decision yet resulting in two legal permits. However, none of the earlier proposals were adopted by Parliament. The approved draft first will go to the legislative section of the Council of State and is expected to be adopted by Parliament in 2014.

According to the explanatory memorandum (Mvt. Voorontwerp van decreet betreffende de omgevingsvergunning, p. 5), the integration of proceedings means the organisation of a permit system in which a global assessment of the environment (milieu), planning and building takes place in one integrated proceeding (one application, one public examination, one piece of advice and

7 See E-UGB-I. The UGB 2009 consist of five books and an introduction Act: Allgemeine Vorschriften und vorhabenbezogenes Umweltrecht(UBGI), Wasserwirtschaft(UGB II), Naturschutz (UGB III), Nichtioni-sierende Strahlung (UGB IV), Handel mit Berechtigungen zur Emission von Treibhausgasen - Emissi-onshandel (UGB V) Einführungsgesetz zum Umweltgesetzbuch (EG UGB).

8 Voorstel van Decreet Stuk 2181 (2003-2004) - пr. 1 and Voorstel van Decreet Stuk 688 (2005-2006) - nr. 1. Both proposals bear a close resemblance. Earlier, in the eighties of the last century, the integration of both permits was also discussed as a result of a draft proposal. However, the final draft the proposal of an integrated permit was dropped. One of the arguments in discussion against the integration was "the different nature of these permits" (both proposals contain explanatory remarks which refer to this history). 
one permit). The main advantage of an integrated assessment is, according to the explanatory memorandum that it leads to more efficiency in the decisionmaking process and better permits in terms of quality (Mvt. Voorontwerp van decreet betreffende de omgevingsvergunning, p. 10). From the Articles 4 and 5 of the draft it follows that the Environmental Permit integrates the permit dealing with the operation of activities and installations that can have an impact on the environment (milieuvergunning), the building permit (stedenbouwkundige vergunning) and an allocation permit (verkavelingsvergunning). The draft proposal is designed in a way that the scope of the Act can be broadened with the use other permits.

It has to be noted that only procedural rules are integrated. The substantive rules will not be integrated into one assessment framework and therefore will remain sectoral. The substantive sectoral rules can be found in the spatial planning act (Vlaamse Codex Ruimtelijke Ordening) and the general rules environmental policy Act (decreet algemene bepalingen milieubeleid).

\subsection{Netherlands: omgevingsvergunning}

In 2010, the Dutch General Act on Environmental Permitting introduced the single environmental permit. In the legislative process four models of environmental permitting were described in a letter to the Lower House (Kamerstukken II 2004/05, 29 383, пг. 18). Models 1 and 2 were based on coordination of different permits. Models 3 and 4 are directed at integrating various permit systems. The main difference is that within a model of integration, one public authority is ultimately responsible. The legislator gave its preference to a model of integration. A system of integrated permit is not totally new in the Netherlands. With the adoption of the Dutch Environmental Management Act in 1993, five permits and two exemptions had already been integrated into a single environmental management permit. Yet the scope of this Environmental Management Act was quite limited, as not all possible permits in the field of environmental law were integrated. The environmental management permit has been absorbed by the GAEP. The environmental permit of the GAEP applies to the demolition, construction, establishment or use of a physical facility. The activities that fall within the scope of the GAEP are typically location-specific projects, which have an impact on physical environment (air, water, soil, wildlife, biodiversity, landscape and cultural and historical elements). It concerns permits such as derogations from obligations of the land-use plan, planning permissions on the Dutch Spatial Planning Act and permits to modify or demolish a protected building under the Dutch Monuments and Historic Building Act 1988. Also, a number of permits required under provincial and municipal by-laws such as advertising display permits and permits for construction, using or changing street access are integrated in the GAEP. Not all the 25 integrated aspects have to be assessed if an application is filed. The scope of the assessment depends on the specific 
activities that the permit is applied for. Most of the environmental permits are included, but not all. The water permit, for example, is still not included.

\section{Model 3}

At present, the GAEP provides a model 3 permit system. The difference between the model 3 and 4 system is the way the assessment framework is shaped. Model 3 has also been referred to as "integration with partitions". This means that the competent public authority evaluates an application for a single environmental permit on the basis of an assessment framework that consists of the sum of the individual, separate assessment frameworks in the various permit systems that have been incorporated in the new permit system. For example, a person wants to build a house and therefore needs a building permit and a derogation from obligations of the land-use plan. In this case, the assessment framework of the single environmental permit contains the sum of the two former assessment frameworks that are now incorporated in the GAEP. This means that the assessment itself is the same as before. The modernisation of the permit system will not introduce new or different standards.

\section{Model 4}

During the legislative process of the GEAP the government's intention was to realise a model 4 permit system in the near future. Model 4 refers to a single integrated assessment framework. An advantage of one single integrated assessment framework is that the competent public authority will be able to consider various aspects of the law (such as the environment (milieu), nature conservation and spatial planning) together, unimpeded by the constraints that having a variety of different assessment frameworks brings. The assumption is that separate assessment frameworks lead to suboptimal decisions from the perspective that the environment should be seen and protected as a whole. The legislator did not elaborate the idea of the model 4 environmental permit in the legislative process. It can be said that the details of this concept are rather hazy (Tolsma, 2012, pp. 82-89). There are, for example, no practical cases that illustrate the problem that can be solved with a model 4 environmental permit. One of the few examples given in literature runs as follows: A plant is located in a building that is indicated as an ancient building on the basis of the Monuments Act. The building needs to be adjusted as a result of changes in the production process of the plant. The rules to protect ancient buildings form an obstacle for the requirements on the basis of environmental legislation. Currently, the environmental permit has to be declined as now the assessment frameworks (protection of monuments and protection of environment) are strictly separated. A model 4 could be shaped in a way that the public authority has power to weigh and balance the aspects of protection of monumental building and environment and decide what is best in the light of "protection of the physical living environment". 
A trade-off between monumental protection and environmental protection could be possible. ${ }^{9}$

The government's intention of introducing one integrated assessment framework has been welcomed by industry and even by environmental groups (Van den Broek \& Rutteman, 2005, pp. 546-549). Some authors have even argued in favour of more far-reaching integration with other aspects, such as water (Van den Broek, 2006, pp. 136-140). There was also support for a model 4 permitting system in the Dutch Lower House. A motion has been adopted in which members of the Lower House have requested that the government present proposals on the substantive integration of assessment frameworks, in a single assessment framework, to the Parliament at that time. ${ }^{10}$ At this moment the model 4 environmental permit is still under discussion. The government is now working on a fundamental system change by restructuring Dutch environmental, spatial and planning law into one Environmental Planning Act. A first draft legislative proposal will be delivered in 2013. ${ }^{11}$ According to the current plans the government has no intention to realise a model 4 environmental permit. ${ }^{12}$ However, scholars still argue in favour of the model 4 environmental permit (Backes, 2012).

\subsection{Comparison}

A comparison between the models of integrated environmental permits described in the sections 2.1-2.4 leads to the following observations:

1. The scope of the Industrial Emissions Directive is limited to the installations listed in Annex I of the directive and by the emissions released into air, water or land during normal operation or through accidents at the installation. The focus is on prevention and control of pollution from these major installations. This means that the construction of installations as well as environmental effects not resulting from emissions (e.g. interference with nature and landscape, impairing the functioning of eco-systems) are not subject to the integrated approach under the IPPC Directive. A model 4 permit has a much broader scope; aspects such as spatial planning and nature conservation are included in a single assessment framework. There are many interests with different natures that need to be protected by the environmental permit.

2. The scope of the proposed substantive integration in the integrierte Vorhabengenehmigung in Germany is in line with the Industrial Emissions

9 This example is based on the tekst of Uylenburg, 2007, p. 59.

10 Handelingen // 2007/08, пг. 34, p. 2618; Kamerstukken // 2007/08, 30 844, пг. 24 (motion members Koopmans en Vermeij).

11 Coalition agreement Bruggen slaan 29 October 2012, p. 38.

12 Toetsversie Omgevingswet, 28 February 2013. 
Directive and therefore limited compared to the idea of the model 4 permit in the Netherlands.

3. The current integrated environmental permit in the Netherlands (model 3) as well as the proposed legislation in Germany and Belgium contains a procedural integration of permit applications in the field of spatial planning or building requirements. The decision-making process results in a single permit, but the assessment frameworks (the substantive rules) remain separated.

To sum up, the idea of realising a model 4 environmental permit can be qualified as highly ambitious. This is due to the broad intended scope of the single integrated assessment framework. The single assessment framework is not limited to industrial effects on the environment (such as waste, air pollution and noise) but also concerns spatial planning, nature conservation etc.

\section{The Model 4 Permit Discussed in Dutch Literature}

The integration of various aspects of environmental law in a single assessment framework will probably result in a fairly broad formulation of the aspects (such as "protection of the physical living environment") in which a permit application will have to be reviewed. The public authority will have more freedom in weighing the interests involved and the variety of different assessment frameworks no longer forms an obstacle to such an integrated assessment. The question is how such a broad assessment framework exactly relates to the Dutch rule of purpose-specific powers. This fundamental principle of Dutch administrative law requires of the legislator that it sufficiently specifies the authority conferred on the administration by providing substantive norms. Schlössels has listed a number of arguments to underpin the necessity of this rule (Schlössels, 1998, pp. 127-132):

- it serves the legislator's prerogative to legislate;

- legitimises administrative authority;

- provides a guideline to the judiciary when testing the legality of administrative action;

- enhances the transparency of administrative organisation and the effectiveness of the decision-making process.

Some scholars take the view that the introduction of a vague and broad formulation of the assessment criteria of the environmental permit (such as "protection of the physical living environment") leads to irresponsible adverse effects in the light of the rule of purpose-specific powers. The safeguarding aspect of this principle will come under pressure (Schlössels, 2006, pp. 153-169; Uylenburg, 2006, pp. 155-166; Blomberg, Michiels, \& Nijmeijer, 2005 , p. 5). They point out a number of legal problems such as reduced judicial control, arbitrariness in the balancing of interests by public authorities 
and diminished legal certainty for individuals and businesses. Other scholars (Backes, 2012, Chapter 3; Van den Broek, 2012, pp. 134-145; Van Hall, 2000, pp. 138-159) are of the opinion that a model 4 permit is in line with the rule of purpose-specific powers, under the condition that the assessment criteria in the light of which a permit application will have to be reviewed, are sufficiently concrete. Various solutions to the possible legal problems are conceivable. For example, an explicit, detailed assessment framework would clearly indicate which aspects should be taken into consideration, and to what extent, in a decision on an application for an environmental permit. This would make it easier to ensure that certain aspects were not ignored. To ensure greater legal certainty and predictability, it would also be possible to lay down further criteria with which a public authority would have to comply when exercising its powers.

\section{Review in the Light of the Dutch Rule of Purpose-specific Powers}

\subsection{Assessment framework}

The question arises how to examine whether or not a model 4 permit leads to irresponsible effects on the safeguarding function of the rule of purposespecific powers. What kind of method of legal research should be used? In the Dutch literature concerning the model 4 permit, I could not detect a clear approach. In my view a normative assessment framework is necessary in order to review model 4 in the light of the rule of purpose-specific powers.

The rule of purpose-specific powers is directed at the legislator. In the Netherlands there is, however, no constitutional law that contains a duty for the legislator to give account to the amount of specificity of administrative powers. The Dutch rule of purpose-specific powers, directed to the legislator, is not codified and is not subject of judicial review. ${ }^{13}$ Compliance with this rule can therefore not be enforced. It is here where the Dutch system differs from German law. The German constitution contains the so-called Bestimmtheitsgebot in Art. 80 (1) of the Grundgesetz. This provision, that sets substantive criteria, can be judged by the Bundesverfassungsgericht and runs as follows: "Durch Gesetz können die Bundesregierung, ein Bundesminister oder die Landesregierungen ermächtigt werden, Rechtsverordnungen zu erlassen. Dabei müssen Inhalt, Zweck und Ausmaß der erteilten Ermächtigung im Gesetze bestimmt werden. Die Rechtsgrundlage ist in der Verordnung anzugeben. Ist durch Gesetz vorgesehen, daß eine Ermächtigung weiter übertragen werden kann, so bedarf es zur Übertragung der Ermächtigung einer Rechtsverordnung."

13 It has to be noted that rule of purpose-specific powers also implies that a rule of administrative law may only be applied within its own well-defined scope and, as a result, may not be used to achieve objectives outside that scope. This element of the rule of purpose-specific powers is subject of judicial review. By virtue of Art. 3:3 of the General Administrative Law Act (Algemene wet bestuursrecht) a public authority may not use its power to make a decision for any other purpose than that for which the power has been given. 
It should be noted that the case law of the Bundesverfassungsgericht does not provide a framework with clear detailed standards that can be used for judicial review. From an analysis of the case law only some very general guidelines can be discerned. For example, the deeper the infringement of the administration upon people's rights and freedoms, the more specific the formulation of administrative authority should be (Schlössels, 1998, pp. 119-122).

A research question that examines whether or not a model 4 permit is in line with the rule of purpose-specific powers is not very useful. This kind of a question is difficult to answer because of the nature of legal principles in general. What are the exact borders of this rule of purpose-specific powers? How compartmentalised should administrative law be precisely? Principles have a certain legal weight or value, but this legal weight or value is not something that can be objectively defined. ${ }^{14}$ In general it can be said that the broader the public authority's assessment of permit criteria are, the more the safeguarding function of the rule of purpose-specific powers will decline (less legal certainty, less judicial review). When we apply this simple rule, we can conclude that a model 4 permit will definitely lead to adverse effects on the safeguarding functions of rule of purpose-specific powers. Are these effects also irresponsible? To answer this normative question I will use the concept of the democratische rechtsstaat as an assessment framework. This concept is closely related to the Rechtsstaatsprinzip and the principle of the rule of law.

The assessment framework of the democratische rechtsstaat (hereafter referred to as "democratic constitutional state") is elaborated by Schlössels \& Zijlstra (2010) in their handbook of Dutch administrative law. The democratic constitutional state consists of different principles, including the rule of purpose-specific powers. It is the government's duty to optimise all principles of the constitutional state. When principles collide, the government has to look for an option made up of the best mixture of those principles. In that case the government needs to consider if compensation for potential negative effects is possible.

The Dutch rule of purpose-specific powers has led to a divided and compartmentalised administration. In the field of environmental law this means that in some instances several permits are required for one single activity (several proceedings, different sets of rules to follow and sometimes even several competent public authorities). This is not only inconvenient for the public, but also for the administration. It must be noted that in the Netherlands the problem of compartmentalised administration also occurs in other fields of law, such as social welfare. According to the legislator,

14 See the well-known distinction between principles and rules, made by Dworkin. Rules have a nature of all or nothing. When a juristic fact occurs, and a rule is valid, the legal effect automatically follows. Legal consequences do not automatically follow from a principle. There is room for consideration. This also means that when two principles are conflicting, it is not clear witch one should prevail in a certain case. It depends on the facts. See Dworkin (1977, pp. 31-39). 
the solution is more discretion for public authorities to decide on a case by case basis. Obviously, the same legal questions related to the rule of purposespecific powers arise in this field of law. ${ }^{15}$ In practice, the effects of the rule of purpose-specific powers seem to be colliding with the principles of efficiency and effectiveness. ${ }^{16}$ This leads to the following question in need of an answer: are the potentially negative effects on the safeguarding functions of the rule of purpose-specific powers, that result from the model 4 permit, necessary for reaching an optimal balance in relation to the principles of efficiency and effectiveness?

\subsection{Review of Model 4 Permit}

Is an environmental model 4 permit a more efficient and effective means necessary for reaching a better system of environmental permits in the Netherlands? In my view the need for a model 4 permit has not been established by the legislator or in literature. It is not clear to me what problem needs to be solved. There is for example no empirical data (an analysis of practical cases) underpinning the necessity of this permit model. The main goal of the GEAP is to make it easier for citizens and businesses to obtain permits. Other aims mentioned as a reason for integrating permits are to reduce the administrative burden and promote cooperation between and within public authorities. With the current model 3 permit system in the GEAP, which provides for procedural integration, proceedings already are combined, harmonised and simplified.

The model 4 permit seems to be based on the holistic idea that the environment should be seen and protected as a whole. The assumption is that a high level of environmental protection can be reached with an integrated approach. Looking at the experiences with the IPPC Directive, it is questionable as to whether we really need these substantive integrated assessment frameworks. Although there is a lack of empirical data on the practical implementation of the IPPC Directive, there are signs that permits involving trade-offs between different environmental media are rare. Bohne's research shows (Bohne, 2008a, pp. 30-33) that national permit systems' potential for substantive integration is relatively low. He concludes that therefore substantive integration is likely to occur even less in actual permit decisions. Another outcome of his research (Bohne, 2006, p. 550) is that the problem of pollution shifting from one medium to another is not often experienced in the practice of decision-making. Public authorities only deal with it from time to time.

The same conclusions can be found in earlier research (Castelein et al., 1998) on the environmental permit of the Environmental Management Act in the Netherlands. One possible explanation given at that time was that there were

15 See Vonk \& Tollenaar (2012, Chapter 1).

16 Schlössels and Zijlstra underline that efficiency and effectiveness also can be qualified as principles of the democratic constitutional state. This view clarifies to their opinion that these aspects also form a part of the normative assessment of government's measures. 
no general criteria available for public authorities to make a cross-medial assessment. Another possible explanation could be that the public authorities are just not capable of making an integrated assessment followed by a decision (Osterhuis, Peeters, \& Uylenburg, 2007). In the Netherlands the public authority usually uses general environmental guidelines (milieurichtlijnen) to set the permit conditions (Leemans, 2008). These guidelines are mostly provided by the government to provide technical and scientific knowledge. Standardisation is another motive for providing model conditions. As a consequence, case-specific considerations will not be taken in to account in the evaluation of a an application.

Bohne states (Bohne, 2008b, p. 327): "It seems that the intellectual fascination of resolving cross-media pollution problems, and the political drive of the British Government to export its previous Integrated Pollution Control (IPC) system to Europe rather practical needs explain to a large extent why holistic integrated permitting is so high on the political agenda in the EU, and only of marginal practical relevance for national permitting authorities."

As long as there is no empirical data to underpin the necessity of a model 4 permit, the undermining of the safeguarding functions of the rule of purposespecific powers cannot be justified.

Furthermore, it is interesting to note that the first empirical data on the permitting model 3 in the Netherlands show that in practice most applications for an environmental permit concern only a single activity. The impression that is given by this research is that applications for a single permit for multiple activities are rare. One possible explanation is that citizens and businesses seeking a permit still have to get used to the new model 3 permit, introduced in 2010 (Uylenburg, 2012, pp. 54-56). Another reason might be that for some projects it is difficult to prepare an application for a single permit for several activities (Borgen et al., 2012). Development of complex projects takes place in different phases over a period of time. Therefore, the preparation of an application for one single permit for the whole project is neither realistic nor useful. These findings from empirical research conflict with the original starting point of the GEAP which is to make applications easier for citizens and businesses. These first experiences with model 3 permits give rise to the question of whether or not we even need a model 3 permit. More in-depth empirical research is necessary to gain better insight in the reasons why citizens and businesses seeking a permit seem to prefer separate permits instead of one single permit. In my view the Netherlands is not ready for a model 4 permit system given that it is questionable whether even the procedural integration of permits (model 3 ) leads to a more efficient and effective system of environmental permits. 


\section{Conclusion}

Environmental law developed originally in a fragmented way. As a result, citizens and businesses applying for a permit are confronted with a range of procedures with a variety of time limits, assessment criteria and legal remedies. It is assumed by policymakers that the fragmented approach in law and policies is both ineffective and inefficient. An integrated approach is necessary in order to achieve a high level of protection for the environment as a whole. At EU level the integrated approach towards pollution control is implemented by means of permits. A comparison of integrated environmental permit models at EU level, Germany, Belgium and the Netherlands leads to the observation that the idea of a so called "model 4" permit system can be qualified as highly ambitious. This permit model considered in the Netherlands refers to a single integrated assessment framework with a much broader scope when compared to the integrated approach of the Industrial Emissions Directive (which is focused on prevention and control of pollution from major installations). The single assessment framework of the model 4 permit contains many interests with different nature that need to be protected by the environmental permit (aspects such as spatial-planning and monumental protection are included).

The question discussed in Dutch literature is how such a broad assessment framework relates exactly to the rule of purpose-specific powers. This fundamental principle of administrative law requires of the legislator that it sufficiently specifies the authority conferred on the administration by providing substantive norms. A single assessment framework with a fairly broad formulation of the aspects in the light of which a permit application will have to be reviewed, will definitely have an adverse effect on the safeguarding elements of this principle. A normative legal question is however, whether or not model 4 will have adverse effects on the safeguarding of the rule of purpose-specific powers. In this article I use the concept of the democratische rechtsstaat as an assessment framework, which is comparable to the principle of the rule of law and the Rechtsstaatsprinzip. The democratic constitutional state consists of different principles, including the principle of the rule of purpose-specific powers. It is the government's duty to optimise all principles of the constitutional state. When principles collide, the government has to look for an optimum combination of those principles. An adverse effect on one of the principles can be justified when this leads to a better balance with other principles. In practice, the effects of the rule of purpose-specific powers seem to be colliding with the principles of efficiency and effectiveness.

Are the adverse effects on the safeguarding functions of the rule of purposespecific powers that result from the model 4 permit necessary for reaching an optimal balance in relation to the principles of efficiency and effectiveness? Looking at the experiences with the IPPC Directive, it is questionable as to whether we really need these substantive integrated assessment frameworks. 
Furthermore, the first experiences in the Netherlands with the current model 3 permit, introduced in 2010 (one application, one competent authority, one single permit) gives the impression that citizens and businesses seeking a permit are not using the possibilities of one single permit and still seem to prefer separate permits. Currently, the need for a model 4 permit has not been established by the legislator nor in literature.

Dr. H.D.Tolsma (Hanna) is Assistant Professor in the Department of Administrative Law and Public Administration at the University of Groningen. She received her PhD in 2008 on a thesis concerning legal aspects of the use of mediation by administrative authorities during the decision-making process. She worked as a postdoc on the research project "Integrated environmental permitting: an exploration of the legal possibility's" sponsored by the Netherlands Organisation for Scientific Research (NWO). Her publications mainly relate to environmental law and administrative (procedural) law. She is a Member of the Advisory Committee for Objections of the Province of Drenthe and an honorary judge at the District Court in the North of the Netherlands. 


\section{Izboljšanje sistemov okoljskih dovoljenj: združena dovoljenja na Nizozemskem}

Ključne besede: okoljska dovoljenja, pristop združitev, združeno okoljsko dovoljenje, pravilo sektorske pristojnosti

Okoljsko pravo se je prvotno razvijalo razdrobljeno, s sektorsko zakonodajo, ki je ščitila vodo, zemljo ali zrak. Takšen pristop k varstvu okolja povzroča težave. Državljani in podjetja, ki uveljavljajo dovoljenja za posege v okolje, se srečujejo z vrsto postopkov z različnimi roki, merili presoje in pravnimi sredstvi. Primerjalno-pravna raziskava kaže, da se zakonodaja na področju okoljskega prava vedno bolj združuje oziroma povezuje. Oblikovalci politik čutijo potrebo, da bi povezali postopke odločanja zaradi optimizacije varstva okolja. Prvi del članka vsebuje kratek pregled koncepta združenega postopka za izdajo okoljevarstvenih dovoljenj. Drugi del obravnava zamisel o okoljskem modelu 4 za dovoljenja, ki je bil predlagan na Nizozemskem. Vprašanje je, ali je ta specifični koncept izdajanja okoljevarstvenih dovoljenj mogoče izvesti v okviru omejitev nizozemskega upravnega prava. 
Improving Environmental Permitting Systems: Integrated Permits in the Netherlands

\section{Bibiliography and references}

Backes, Ch. W. (2012). Integraal en flexibel omgevingsrecht-droom of drogbeeld. Naar een nieuw omgevingsrecht, Preadviezen Vereniging voor Bouwrecht, 40, 31-51.

Blomberg, A. B., Michiels F. C. M. A., \& Nijmeijer, A. G. A. (2005).

Vergunningverlening in het omgevingsrecht: naar stroomlijning of integratie? Tijdschrift Omgevingsrecht, 1, 3-11.

Bohne, E. (2006). The Quest for Environmental Regulatory Integration in the European Union. Alphen aan den Rijn: Kluwer Law International.

Bohne, E. (2008a). The implementation of the IPPC Directive from a comparative perspective and lessons for its recast (Part I). Journal for European Enviromental \& Planning Law, 5(1), 1-33.

Bohne, E. (2008b). The implementation of the IPPC Directive from a comparative perspective and lessons for its recast (Part II). Journal for European Enviromental \& Planning Law, 5 (3), 319-338.

Bohne, E. \& Dietze, D. (2004). Pollution Prevention and Control in Europe Revisited. European Environmental Law Review, 13 (7), 198-217.

Borgers, H. C. et al. (2012).W@BO. Een evaluatie van gebruikerservaringen met de Wabo en het Omgevingsloket online. AT Osborn.

Castelein, A. et al. (1998). Meer dan de som der delen? Een onderzoek naar de aard van de afwegingen bij de opstelling van milieuvergunningen, Achtergrondstudie ECW, nг. 34.

Dworkin, R. (1977). Taking rights seriously. Cambridge, MA : Harvard University Press.

Knopp, L. (2009). Umweltgesetzbuch - ein Trauerspiele ohne ende? Umwelt und Planungsrecht, 4, 121-125.

Leemans, T. C. (2008). De toetsing door de bestuursrechter in milieugeschillen (diss. Leiden). Den Haag: BJu .

Müggenborg, H. \& Hentschel, A. (2010). Neues Wasser- und Naturschutzrecht. Neue Juristische Wochenschrift, 14, 961-967.

Oosterhuis, F. H., Peeters, M. G. W. M., \& Uylenburg, R. (2007). Het beoordelingskader van de IPPC richtlijn. Implementatie, interpretatie en toepassing, STEM 2007/1.

Scheidler, A. (2009). Die anstehende Neuordnung des Umweltrechts nach dem Scheitern des Umweltgesetzbuch. Umwelt und Planungsrecht, 5, 173-176.

Schlössels, R. J. N. (1998). Het specialiteitsbeginsel: over de structuur van bestuursbevoegdheden, wetmatigheid van bestuur en beleidsvrijheid (diss. Maastricht). Den Haag: SDU Uitgevers.

Schlössels, R. J. N. (2006). De ondraaglijke lichtheid van het specialiteitsbeginsel. lets over integratie van bestuursbevoegdheden, coördinatie van besluiten en rechtsbescherming. In A. W. Heringa et.al. Het bestuursrecht beschermd (pp. 153-169). Den Haag: SDU Uitgevers.

Schlössels, R. J. N. \& Zijlstra, S. E. (2010). Bestuursrecht in de sociale rechtsstaat. Deventer: Kluwer.

Tolsma, H. D. (2012). Omgevingsvergunning model 4 een stap dichterbij met de Omgevingswet? Tijdschrift Milieu \& Recht, 2, 82-89. 
Uylenburg, R. (2006). De omgevingsvergunning en het specialiteitsbeginsel. In K. J. De Graaf, A. T. Marseille, \& H. B. Winter (Eds.), Op tegenspraak (Damenbundel) (pp. 155-166). Den Haag: BJu.

Uylenburg, R. (2007). De omgevingsvergunning en de grenzen aan integratie In Aan de grens van de milieuvergunning, Vereniging voor milieurecht 2007-5.

Uylenburg, R. (2012). De omgevingsvergunning in een nieuwe habitat. In Naar een nieuw omgevingsrecht (Preadviezen Vereniging voor Bouwrecht nr. 40), (pp. 53-72).

Van den Broek, J. H. G. (2012). Bundeling van omgevingsrecht (diss. Maastricht). Deventer: Kluwer.

Van den Broek, J. H. G. \& Rutteman, J. (2005). Bedrijfsleven en milieubeweging steunen Wabo. Tijdschrift Milieu \& Recht, 9, 546-549.

Van den Broek, J. H. G. (2006). Kroonjuwelen met scherpe randjes. Tijdschrift Omgevingsrecht, 4, 136-140.

Van Hall, A. (2000). Belangenafweging in de wet op de fysieke omgeving. In A. Driesprong et.al., Lex aquarum, Liber amicorum. Opstellen over waterstaat, waterstaatswetgeving en wetgeving, opgedragen aan J.H.A. Teulings (pp. 138-159). Den Haag: Ministerie van Verkeer en Waterstaat.

Vonk, G. J. \& Tollenaar, A. (Eds.) (2012). Lokale verzorgingsstaat: nieuwe uitdagingen voor de sociale rechtsstaat. Bestuursrecht \& Bestuurskunde Groningen 2012. 